University of Nebraska - Lincoln

DigitalCommons@University of Nebraska - Lincoln

Faculty Publications from the Harold W. Manter Laboratory of Parasitology

6-1975

Phyllodistomum scrippsi sp. n. (Digenea: Gorgoderidae) and Neobenedenia girellae (Hargis, 1955) Yamaguti, 1963

(Monogenea: Capsalidae) from the California Sheephead, Pimelometopon pulchrum (Ayres) (Pisces: Labridae)

Daniel R. Brooks

University of Toronto,dnlbrooks@gmail.com

Monte A. Mayes

University of Nebraska - Lincoln

Follow this and additional works at: https://digitalcommons.unl.edu/parasitologyfacpubs

Part of the Parasitology Commons

Brooks, Daniel R. and Mayes, Monte A., "Phyllodistomum scrippsi sp. n. (Digenea: Gorgoderidae) and Neobenedenia girellae (Hargis, 1955) Yamaguti, 1963 (Monogenea: Capsalidae) from the California Sheephead, Pimelometopon pulchrum (Ayres) (Pisces: Labridae)" (1975). Faculty Publications from the Harold W. Manter Laboratory of Parasitology. 242.

https://digitalcommons.unl.edu/parasitologyfacpubs/242

This Article is brought to you for free and open access by the Parasitology, Harold W. Manter Laboratory of at DigitalCommons@University of Nebraska - Lincoln. It has been accepted for inclusion in Faculty Publications from the Harold W. Manter Laboratory of Parasitology by an authorized administrator of DigitalCommons@University of Nebraska - Lincoln. 


\title{
PHYLLODISTOMUM SCRIPPSI SP. N. (DIGENEA: GORGODERIDAE) AND NEOBENEDENIA GIRELLAE (HARGIS, 1955) YAMAGUTI, 1963 (MONOGENEA: CAPSALIDAE) FROM THE CALIFORNIA SHEEPHEAD, PIMELOMETOPON PULCHRUM (AYRES) (PISCES: LABRIDAE)
}

\author{
Daniel R. Brooks* and Monte A. Mayes \\ School of Life Sciences, University of Nebraska-Lincoln and Harold W. Manter Laboratory, \\ Division of Parasitology, University of Nebraska State Museum, Lincoln, Nebraska 68508
}

\begin{abstract}
Phyllodistomum scrippsi sp. n. is described from the urinary bladder and Neobenedenia girellae is reported from the skin of Pimelometopon pulchrum from La Jolla, California. Phyllodistomum scrippsi differs from $P$. borisbychowskyi in possessing lobed vitellaria, fewer extracecal uterine loops, irregular to lobed gonads, and larger eggs; and from P. acceptum in possessing a short esophagus, nondigitiform vitelline lobes, and an oral sucker larger than the acetabulum. An annotated checklist of trematodes parasitizing $P$. pulchrum is given.
\end{abstract}

A specimen of the California sheephead, Pimelometopon pulchrum (Ayres), was collected off La Jolla, California, in March 1974. The urinary bladder contained eight specimens of an unreported species of Phyllodistomum Braun, 1899 (Digenea: Gorgoderidae), and over 100 specimens of the monogenean Neobenedenia girellae (Hargis, 1955) Yamaguti, 1963, were found on the skin.

The digeneans were fixed in situ with hot AFA, removed from the urinary bladder, and stored in 70\% ethanol. Monogeneans were collected as suggested by Rogers (1966) and stored in $10 \%$ formalin. All worms were stained with Mayer's hematoxylin and mounted in Canada balsam for study as whole mounts. Figures were drawn with the aid of a camera lucida. All measurements are in microns unless otherwise stated.

\section{Phyllodistomum scrippsi sp. n.}

(Figs. 1, 2)

Description (measurements based on 8 adult specimens): Body broadly pyriform, $3.936 \mathrm{~mm}$ to $4.584 \mathrm{~mm}$ long by $3.198 \mathrm{~mm}$ to $3.28 \mathrm{~mm}$ wide. Oral sucker subterminal, 517 to 615 long by 508 to 680 wide; acetabulum 410 to 492 long by 410 to 541 wide; ratio of sucker widths $1: 0.8$. Esophagus 246 to 328 long; cecal bifurcation preacetabular, ceca ending near posterior end of body. Testes large, irregular to lobate, oblique; in midhindbody. Seminal vesicle saccular, preacetabular. Genital pore median, midway between acetabulum

Received for publication 25 November 1974.

* Present address: Gulf Coast Research Laboratory, Ocean Springs, Mississippi 39564. and bifurcation. Ovary pretesticular, irregular, smaller than testes, submedian, dextral or sinistral. Mehlis' gland and Laurer's canal present. Vitellaria immediately postacetabular, paired, irregular to lobed. Uterus extensive, filling most of hindbody, with extracecal loops posterior to level of vitellaria, and distal, saccular swelling near genital pore. Eggs 38 to 40 long and 22 to 26 wide. Excretory pore subterminal, dorsal, with associated gland cells; excretory vesicle I-shaped, reaching intertesticular area.

Host: Pimelometopon pulchrum (Ayres), California sheephead.

Locality: Kelp beds off La Jolla, California.

Location: Urinary bladder.

Type specimens: Holotype and paratype USNM Helm. Coll. Nos. 73815, 73816. Two paratypes H. W. Manter Laboratory No. 20073. Other paratypes in collections of authors.

\section{Remarks}

Phyllodistomum scrippsi most closely resembles $P$. borisbychowskyi Caballero and Caballero, 1969, and P. acceptum Looss, 1901. It differs from $P$. borisbychowskyi in possessing large, irregular gonads and lobed vitellaria rather than small round gonads and vitellaria, uterine loops which do not extend as far anteriorly, and larger eggs. It differs from $P$. acceptum in possessing a short esophagus, nondigitiform vitelline lobes, and an oral sucker larger than the acetabulum. The host for $P$. borisbychowskyi, Gibbonsia metzi (Hubbs), was collected less than 100 miles north of La Jolla, and, though representing a different family (Clinidae), occupies a similar ecological niche as Pimelometopon pulchrum. Phyllodistomum acceptum has been reported only 


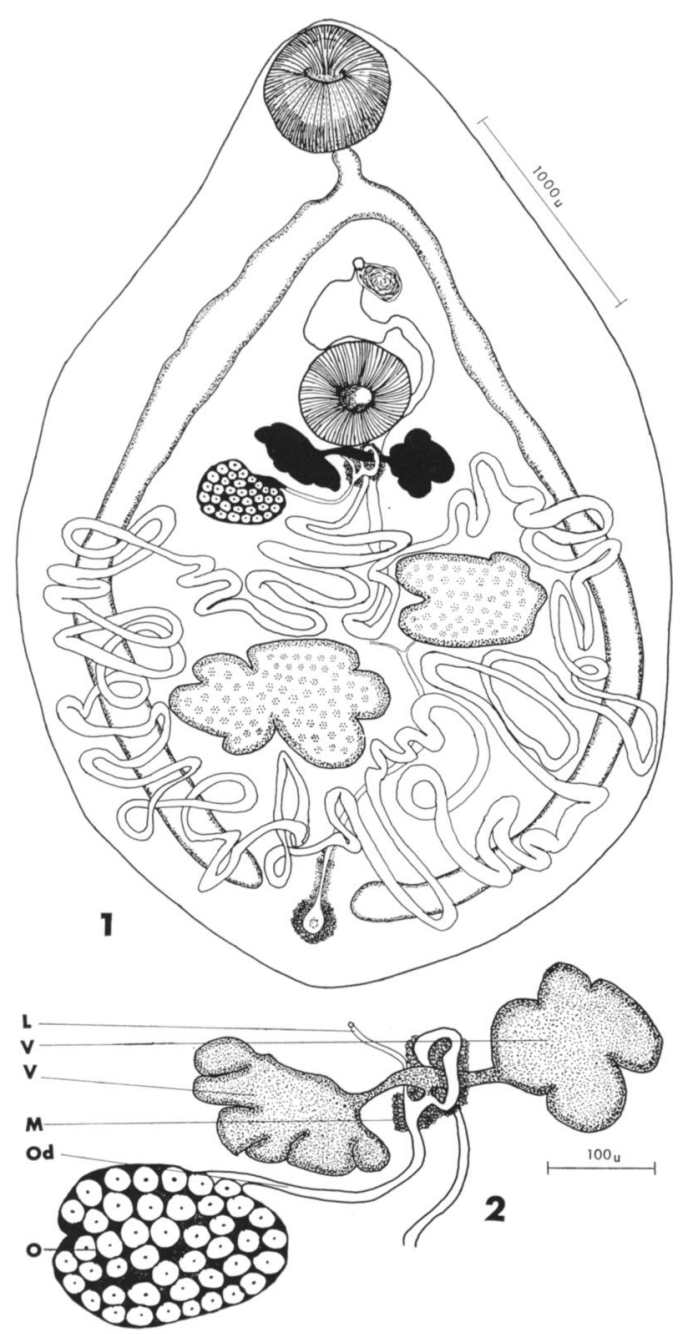

Figures 1, 2. Phyllodistomum scrippsi sp. n., holotype. 1. Ventral view. 2. Ootype region. Abbreviations: L, Laurer's canal; M, Mehlis' gland; $\mathrm{O}$, ovary; Od, oviduct; V, vitellarium.

from Crenilabrus griseus (Gmelin apud L.) and C. pavo (Brunnichius) in the Black Sea, fish which belong to the same family (Labridae) as Pimelometopon pulchrum.

\section{Neobenedenia girellae (Hargis, 1955) Yamaguti, 1963}

Neobenedenia girellae has previously been reported from Girella nigricans (Ayres) from La Jolla (Hargis, 1955) and Mycteroperca pardalis Gilbert from Baja California (BravoHollis, 1958). This report from Pimelometopon pulchrum constitutes a new host record, and is the first report of a monogenean from that host.

Three additional digeneans are known to parasitize Pimelometopon pulchrum:

Labrifer secundus Manter, 1940, from Cedros Island, Baja California (Manter, 1940), La Jolla, California (Montgomery, 1957), and La Jolla, California and 52.5 nautical miles east of Isla Guadaloupe, Mexico (Pritchard, 1972).

Lepocreadium bimarinum Manter, 1940, from Cedros Island, Baja California (Manter, 1940), and La Jolla, California (Montgomery, 1957).

Neolabrifer bravoae Pritchard, 1972, from La Jolla and Point Loma, California and 52.5 nautical miles east of Isla Guadaloupe, Mexico (Pritchard, 1972).

\section{ACKNOWLEDGMENTS}

The authors would like to express their appreciation to Mr. Douglas Diener, Scripps Institution of Oceanography, for his aid in collecting fish and parasites; and to Mrs. Mary Hanson Pritchard, Curator of the Manter Laboratory, for her invaluable aid and direction in the preparation of the manuscript.

\section{LITERATURE CITED}

Bravo-Hollis, M. 1958. Tremátodos de peces marinos de aguas méxicanas. XIV. Cuatro monogéneos de la familia Capsalidae Baird, 1853, de los costas de Pacífico, incluyendo una especie neueva. An. Inst. Biol. Univ. Nac. Méx. 28: 195-216.

HARGIS, W. J., JR. 1955. A new species of Benedenia (Trematoda: Monogenea) from Girella nigricans, the opaleye. J. Parasit. 41: 48-50.

Manter, H. W. 1940. Digenetic trematodes of fishes from the Galapagos Islands and the neighboring Pacific. Rep. Allan Hancock Pac. Exped. (1932-1938) 2 (14) : 325-497.

Montgomery, W. R. 1957. Studies on digenetic trematodes from marine fishes of La Jolla, California. Tr. Am. Micr. Soc. 56: 13-36.

Pritchard, Mary H. 1972 . Neolabrifer bravoae gen. nov. sp. nov. and Labrifer secundus Manter, 1940 (Trematoda: Lepocreadiidae) from the California sheephead in the American Pacific. An. Inst. Biol. Nac. Méx. 41 (Ser. Zool.): 127-134.

Rogers, W. R. 1966. Three new species of Pseudomurraytrema (Trematoda: Monogenea) from gills of catostomid fishes. J. Parasit. 52 : 462-465. 